\title{
Implementation of Group Investigation Cooperative Learning Model in Increasing student learning participation
}

\author{
Ahmad Yudianto 1 ${ }^{*}$,Askar Askar 2,and Moh. Ali ${ }^{3}$ \\ ${ }^{1}$ Islamic Education Department, Postgraduate, State Islamic Institute Palu \\ 2 Islamic Education Department, Postgraduate, State Islamic Institute Palu \\ ${ }^{3}$ Islamic Education Department, Postgraduate, State Islamic Institute Palu
}

\begin{abstract}
The aim of this paper is to discusses the practice of cousin marriage in the community of Kalola Village, Pasangkayu Regency, West Sulawesi. This study uses qualitative methods and data was gathered through observation, in-depth interviews, and written material. Data analysis was analyzed using a grounded theory approach. The results showed that the learning participation of students in the implementation of the cooperative learning model type Group Investigation before, namely: from 20 students that, the results of student participation in interaction activities were classified as low seeing the students, compiling only 7 people, responding (asking and answering ) only 5 people and accepted in the teacher's explanation only 10 people and and the indicator of students' learning participation was low as seen from the skill scores of these students, while after the implementation of the cooperative learning modeltype group investigation experienced a significant increase, there were 20 students. That the results of student participation in interaction activities compose 19 people, respond (ask and answer) 14 people, and accept in the teacher's explanation 14 people and indicators of increasing student learning participation also increase, it can be seen that the skill value of these students.
\end{abstract}

\section{ARTICLE \\ INFORMATION}

\section{Keywords:}

Group investigation, cooperative learning, students, participation 


\section{Introduction}

Education is the key to all progress in quality growth and development because, with education, humans can realize all their potential either as individuals or as citizens of the community or nation and state. In order to realize the quality or potential of a person into multiple competencies, they must go through an educational process that is implemented in the learning process. The education system in Indonesia has undergone various changes. These changes are the result of various reform efforts made by the government in the field of education. ${ }^{1}$ Renewal efforts in the field of education are carried out in order to improve the quality of education.

One of the efforts to improve the quality of education in schools/madrasahs is by improving learning. New concepts or descriptions and insights about learning in schools/madrasahs have emerged and developed along with the rapid development of science and technology. Learning at school is a series of consciously planned activities. Good planning will support the success of learning. Few Learning efforts are being pursued so that students can participate and increase learning motivation, challenges, and satisfaction so that they can meet expectations, both by educators as material carriers and students, as cultivators of knowledge.

\footnotetext{
${ }^{1}$ Rusli, R. (2014). Teaching Usul al-Fiqh: A Multicultural Education Model. Al-Tahrir: Jurnal Pemikiran Islam, 14(2), 447-464.
}

The success of teaching and learning activities in class really depends on educators' ability to design the learning process. In designing learning activities, several aspects need to be considered by educators, one of which is the use of an appropriate learning model.

In this study, the researcher tried to examine the application of the learning model group investigation in the learning process. Group investigation can be used as an alternative to learning to increase student participation. The learning model investigation group requires students to have good abilities in communicating and in group process skills. The model group investigation can train students to foster their ability to think independently, as well as, so students are able to choose the topic they want to study, followinvestigations depth of various subtopics that have been selected, then prepare and present a report in front of the class as a whole.

Therefore, in cooperative learning, the model group investigation, social interaction is an important factor for the development of new mental schemes. In this learning, it gives learners the freedom to think analytically, critically, creatively, reflectively, and productively. $^{2}$

Therefore, this research was conducted with a theme related to this type of learning, which is Group Investigation model, with the aim of increasing the participation and learning outcomes of students in the fiqih subject.

\footnotetext{
2 Hamzah B, dan Nurdin Mohamad, Belajar dengan Pendekatan PAILKEM (Cet. I; Jakarta: PT Bumi Akasara, 2011), 224.
} 
Students are a form of mental and emotional involvement of students to encourage students to contribute and be responsible for achieving a goal, namely achieving satisfactory achievement. By using communicative and creative learning, educators must always carry out self-development, with various things such as seminars and training.

Cooperative learning is in accordance with the nature or nature of human origin as social beings who are full of dependence on others, have common goals and responsibilities, division of tasks, and a sense of the same fate. Students are trained and accustomed to sharing knowledge, experiences, assignments, and responsibilities through cooperative learning or group learning. Helping each other and practicing interaction, communication, and socialization because cooperation is a miniature of social life and learning to realize each's weaknesses and strengths.

Conscious, cooperative learning creates mutually honing interactions so that learning resources for students are not only educators and textbooks but also fellow students.

\section{Literature Review}

\subsection{Cooperative Learning using Group Investigation model type}

The learning model is a package or frame of the application of an approach, method, and learning techniques as well as a reference or guide in carrying out an activity. The term learning model is closely related to understanding learning strategies. The term strategy was originally known in the military world, especially in connection with war or the world of sports. However, this meaning extends not only to the world of the military or sports but to the economic, social, and educational fields learning model is a package or frame of the application of an approach, method, and learning techniques as well as a reference or guide in carrying out an activity. The term learning model is closely related to understanding learning strategies. The term strategy was originally known in the military world, especially in connection with war or the world of sports.

However, this meaning extends not only to the world of the military or sports but to the economic, social, and educational fields. $^{3}$ In educational practice, the model is closely related to learning, so that this model is a supporting factor for the learning process. Therefore it is known as a learning model.

According to Kemp in Rusman, the learning model is "a learning activity that must be done by educators and students so that learning objectives can be achieved effectively and efficiently". 4

As for the opinion of Kemp, Dick and Carey in Rusman also argues that the learning model is a learning procedure material device that is used together to

\footnotetext{
${ }^{3}$ Suryosubroto, Proses Belajar Mengajar di Sekolah (Jakarta: PT Rineka Cipta, 2007), 23.

4Rusman, Model-Model Pembelajaran: Mengembangkan Profesional Guru (Ed. II; Jakarta: PT Raja Grafindo Persada, 2010), 132. 
produce learning outcomes in students or students. ${ }^{5}$

According to the above opinion, it can be concluded that a device of learning procedure material is used together to produce learning outcomes in students so that learning objectives can be achieved effectively and efficiently.

Therefore, the learning model is a teaching plan that shows certain learning patterns. In this pattern, it can be seen that the activities of educators and students in realizing learning conditions or environmental systems that cause the learning process to occur in students.

1. Basic Considerations for Choosing a Learning Model

Before determining the learning model to be used in learning activities, there are several things that educators should consider in choosing it, as follows.

The choice of strategy or learning model can be made by paying attention to the questions below.

a) Consideration of the goals to be achieved. The questions that can be asked are:

- What are the learning objectives to be achieved about academic, personal, social and vocational competences or what was previously termed the cognitive, affective or psychomotor domains?

- What is the complexity of the learning objectives to be achieved?

- Does achieving that goal require academic skills?

5Ibid., 132. b) Considerations related to learning materials or materials:

- Is the subject matter in the form of facts, concepts, laws or certain theories?

- Does learning material require prerequisites or not?

- Are there relevant materials or resources for studying the material?

c) Consideration from the point of view of students or students:

- Is the learning model in accordance with the maturity level of students?

- Is the learning model in accordance with the interests, talents, and conditions of students?

- Is the learning model in accordance with the learning styles of students?

d) Other non-technical considerations:

- Is it enough to achieve the goal with just one model?

- Is the learning model that we set considered the only model that can be used?

- Does the learning model have effectiveness or efficiency values. ${ }^{6}$

The following is an example of choosing a strategy or learning model based on the principles of efficiency, effectiveness, and student involvement.

a. Efficiency

The most efficient model for achieving the TPK is the expository strategy, in which the participant's activities are as follows.

1) Ask students to show and name the wild animal species in the picture.

6Nurdyansyah dan Eni Fariyatul Fahyuni, Inovasi Model Pembelajaran: Sesuai Kurikulum 2013 (Cet. I; Sidoarjo; Nizamia Learning Center, 2016), 21.

e-ISSN: 2715-4572 p-ISSN: 2716-1439 
2) Ask students to pay attention to the characteristics of wild animals that appear in the picture.

3) As a follow-up, students are asked to memorize these characteristics as a task at home.

4) Then in the questions, their duties were asked again.

5) What if students can answer correctly, then they are considered to have achieved the learning objectives.

b. Effectiveness

Effectiveness is aimed at answering the question of how far students have achieved the learning objectives. Keep in mind that even the most efficient models are not automatically effective strategies. To be able to measure the effectiveness of a learning objective, it can be done by determining how far the concepts that have been learned and can be transferred (transferability) to the next subject or practical application in everyday life. ${ }^{7}$

The difference between the level of efficiency and effectiveness in selecting the learning model can be explained as follows. Namely, if the learning objectives can be achieved in a shorter time through a strategy than other models, then the strategy is said to be quite efficient in achieving the goal. Meanwhile, suppose the implementation of a strategy compared to other

\footnotetext{
${ }^{7}$ Evita, E., Syahid, A., \& Nurdin, N. (2019). Understanding Students' Learning Outcomes Differences Through the Application of the Market Place Activity Type of Cooperative Learning Model and the Application of Conventional Learning Models International Journal of Contemporary Islamic Education, 1(1), 6785.
}

strategies can make participants have a greater ability to transfer information or skills that have been learned. In that case, the strategy is said to be quite effective in achieving learning tasks. c. Student

Students' involvement in the learning process is strongly influenced by challenges that can generate motivation in learning. Learning Strategies that are inquiry generally provide a stimulus to learn more intensive compared to learning strategies purely expository. Despite the fact, the two types of models cannot be separated explicitly. For this reason, educators must be creative in combining the two by considering various components or learning that are thought to affect the process. In today's modern learning process, what is more, important is how to activate the involvement of students or learners in the learning process independently, namely through learning activities oriented to discovery and search. ${ }^{8}$

2.2 Factors Affecting the Learning Model In learning activities, several factors influence the learning model, including the factors of teachers, students, facilities and infrastructure, and environmental factors.

a. Educator factors

Educators are a very determining component in the application of a learning strategy. Without the teacher, however good and ideally a learning strategy is, it is impossible to apply just

30.
${ }^{8}$ Mohamad, Belajar dengan Pendekatan, 28-

e-ISSN: 2715-4572

p-ISSN: 2716-1439 
like a soldier on the battlefield. The success of implementing a war strategy to destroy the enemy will significantly depend on the quality of the soldiers themselves, likewise, with teachers. The success of implementing a learning strategy will depend on the expertise of the teacher in using learning methods, techniques, and tactics. ${ }^{9}$ Each teacher has different experiences, knowledge, abilities, styles, and even views in teaching. Teachers who think teaching is limited to delivering subject matter will be different from teachers who think teaching is a process of providing assistance to students. Each of these differences can affect both the formulation of strategies and the application of learning.

\section{b. Learners}

Learners are unique organisms that develop according to their developmental stages. The development of students in all aspects of their personality, not only the tempo and rhythm of each student's development is different in every aspect. Learning activities can be influenced by the development of different learners, in addition to other characteristics inherent in students.

c. Facilities and infrastructure

Facilities are everything that directly supports the smooth running of learning activities, for example, learning media, learning tools, school supplies,

${ }^{9}$ Nurdin, N., Pettalongi, S. S., \& Ahsan, M. N. (2019, 30-31 July 2019). Implementation of Teaching Quality Assessment System Using Android. 2019 5th International Conference on Science and Technology (ICST), and so on. Meanwhile, infrastructure is anything that can indirectly support the success of learning activities, for example, the road to the madrasah, madrasah lighting, toilets, and so on. Completeness of facilities and infrastructure will help teachers implement learning activities; thus, facilities and infrastructure are important components that can affect learning activities.

d. Environment

As seen from the environmental dimension, there are two factors that can influence learning activities, namely class organization factors and sociopsychological climate factors. Class organization factors, which include the number of students in one class, are important aspects that can affect learning activities.

Another factor from the environmental dimension that can affect learning activities is the sociopsychological climate factor. That is harmonious relationships between people involved in learning activities. This social climate can occur internally or externally.

The internal socio-psychological climate is the relationship between people involved in the madrasah environment, for example, the social climate between students and students, between students and teachers, between teachers and teachers, even between teachers and school/madrasah leaders. The external socio-psychological climate is the harmonious relationship between the madrasah and the outside world, for example, the relationship between the madrasah and the parents of students, 
the relationship between madrasas and community institutions, and so on. ${ }^{10}$

Schools or madrasah that have good relationships internally, shown by inter-teacher cooperation, mutual respect and respect, help each other, allow the learning climate to be cool and calm so that it will impact the learning motivation of students. Conversely, when the relationship is not harmonious, the learning climate will be full of tension and discomfort so that it will affect the psychology of students in learning. Likewise, madrasah that has good relations with outside institutions will increase the smooth running of madrasah programs, so that madrasah efforts to improve the quality of learning will receive support from other parties.

\section{Methodology}

This study used a qualitative approach with the research object, namely Madrasah Madinatul Ilmi Alkhairaat Dolo, Sigi Regency. This madrasah is a madrasah that implements a type of cooperative learning model group investigation on fiqih subjects.

The use of qualitative methods in this study does have several considerations. First, adapting qualitative methods is easier when faced with multiple realities. Second, it can directly present the nature of the relationship between researchers and informants ${ }^{11}$. Third, this method is more

10Wina Sanjaya, Strategi Pembelajaran: Berorientasi Standar Proses Pendidikan (Cet,II; Jakarta: Kencana, 2007), 52-57.

11 Nurdin, N. (2017a). Research in Online Space: The Use of Social Media for Research sensitive and adapts itself to a lot of sharpening a common guide and to the value patterns faced. ${ }^{12}$

Data were collected using observation techniques, in-depth interviews with principals, teachers, and students. Researchers also reviewed various written documents ${ }^{13}$. Meanwhile, data analysis was performed using reduction and verification techniques with various data sources. ${ }^{14}$ The data that has been reduced is then analyzed by confessing the theoretical concepts used in this study.

\section{Results and Discussion}

\subsection{Implementation of Group Investigation with Group Cooperative Learning Model}

Data obtained by researchers from the field is the result of data from observations, interviews, and documentation. This is related to "The implementation of the type Cooperative Learning Model Group Investigation in increasing students' learning participation in the Class VIII B, Fiqih

\footnotetext{
Setting Jurnal Sistem Informasi (Journal of Information System), 13(1), 67-77.

12Ibid., 5.

13 Nurdin, N. (2017b). To Research Online or Not to Research Online: Using Internet-Based Research in Islamic Studies Context. Indonesian Journal of Islam and Muslim Societies, 7(1), 31-54.

14 Nurdin, N., \& Yusuf, K. (2020). Knowledge management lifecycle in Islamic bank: the case of syariah banks in Indonesia. International Journal of Knowledge Management Studies, 11(1), 59-80. https://doi.org/10.1504/ijkms.2020.105073
} 
Subject at MTs Alkhairaat Madinatul Ilmi Dolo," then the researcher tries to dig directly and deepen the available data as much as possible. Research focus.

Efforts to increase the learning participation of students, there are many methods or learning models used by the teacher so that these students can actively participate in learning both in the school/madrasah environment and outside. In the Fiqih subject, the teacher used the type cooperative learning model, and group investigation is to increase the learning participation of students according to the material being taught. Because the type of cooperative learning model and group investigation can make students feel mutual cooperation, and account for each group in solving these problems.

1. Learning Implementation Design

The cooperative learning model type group investment is carried out for students as a step in increasing student learning participation in order to develop knowledge. This type of cooperative learning model investment group is expected to optimize the learning process, especially in increasing the learning participation of students in Fiqih subjects. The learning implementation design is a device used as a guide to a teacher in implementing a way of making RPP; usually, it can also help teachers teach in class. The results of the interviews by the fiqh subject teachers stated that in designing the implementation of learning or lesson plans as follows:

a) Identity of subjects

b) standards c) CompetencyBasic competencies

d) Learning objectives Learning

e) materials Learning

f) methods Learning

g) steps Learning

h) resources and learning media

i) assessment. ${ }^{15}$

According to research observers, before the teacher enters the class, the teacher first prepares a lesson plan or lesson plan so that the learning can be directed as described above. Then the teacher teaches the material of fasting with the expected objectives. There are different Characteristics of student that are religious, honest, independent, democratic, communicative, and responsible.

According to research observers, MTs. Alkhairaat Madinatul Ilmi Dolo is part of the Islamic Boarding School, so the deepening of religion and morals is prioritized compared to conveying science and technology. Faith and devotion to Allah Subhanahu Wa Ta'ala to foster character or morals, and devotion to religion, society, and the State.

2. The Learning Model Training Process for Teachers

MTs Alkhairaat Madinatul Ilmi Dolo is a madrasah that has a vision of creating a superior in achievement, skilled, and has good character; from this vision course, teachers play a major role in making it happen. Teachers who apply the cooperative learning model type of investment group are teachers

\footnotetext{
${ }^{15}$ Irmayanti Iroth, S.Ag., Guru Fikih MTs Alkhairaat Madinatul Ilmi Dolo, Wawancara. Ruang Guru. 15 Oktober 2019

e-ISSN: $2715-4572$ p-ISSN: 2716-1439
} 
who have been trained in their field, in accordance with the statement of the fiqih teacher said.

The Ministry of Religion held training on learning models, and MTs Madinatul Ilmi Dolo participated in this activity where other teachers and I gave the mandate to participate in this activity for two meetings. ${ }^{16}$

The training, as stated by the fiqih teacher, Irmayanti Iroth, are as follows.

a) Public lecture: understanding the learning models.

b) Public lecture: how to make lesson plans based on learning models involving character education.

c) Workshop: making lesson plans based on learning models.

d) Simulation and revision of participant workshop results.

e) Presentation of results. ${ }^{17}$

From the statement above, it is clear that applying learning models effectively, of course, it is necessary to take part in training, especially training that can improve teacher teaching quality and how to manage a good classroom. The implementation of the cooperative learning model type group investments an effort made to increase the participation of students in the class, especially in fiqih.

In making participants skilled, of course, teachers are required to be creative in the learning process, where in

\footnotetext{
16Irmayanti Iroth, S.Ag., Guru Fikih MTs Alkhairaat Madinatul Ilmi Dolo, Wawancara. Ruang Guru. 15 Oktober 2019

17Irmayanti Iroth, S.Ag., Guru Fikih MTs Alkhairaat Madinatul Ilmi Dolo, Wawancara. Ruang Guru. 15 Oktober 2019
}

addition to applying the cooperative learning model type investment group, the teacher also provides various learning methods. Irmayanti Iroth, stated that:

In the fiqih subject, of course, I do not apply just one kind of learning model, but I also apply other learning models according to the material, including lectures, discussions, exhibitions and shopping and groups. ${ }^{18}$

According to the researcher's observations, in teaching fiqih, teachers use cooperative learning model group investigation and use the methods of lectures, discussions, exhibitions, and shopping, and groups according to the material provided.

Implementation of the type of cooperative learning with model group investigation. This is expected to make it easier to convey the material and so that students can understand the material presented more quickly.

Related to this, Khalil Jibbun Figiawan, a student of class VIII B who stated:

I feel happy if the teacher applies the type cooperative learning model group investigation because we can work together and can appear in front of the class to explain; I like this method and understand more quickly. ${ }^{19}$

18Irmayanti Iroth, S.Ag., Guru Fikih MTs Alkhairaat Madinatul Ilmi Dolo, Wawancara. Ruang Guru. 15 Oktober 2019

${ }^{19}$ Khalil Jibbun Figiawan, Peserta didik Kelas VIII B MTs Alkhairaat Madinatul Ilmi Dolo, Wawancara. Ruang Kelas. 25 September 2019 
Based on the observations, the researcher saw that when teachers apply the type of cooperative learning model and group investigation, besides making it easier for the teacher to deliver the material because the teacher had prepared the material in cardboard form so that later students were given the task to investigate the material and explain in front of the class in this way students were more focused because students played an active role in it and also enthusiastic students. In learning and better understand the material provided.

3. The Teacher's Obligations in Teaching in the Class of

MTs Madinatul Ilmi Dolo in carrying out the teacher's teaching duties are in accordance with the statement of the Head of Madrasah Tsanawiyah Rosita, S.Pd. among others, are as follows:

a) Teachers should prioritize the main sciences because their substance is from the tools sciences as a learning method.

b) Teachers should pay attention to the readiness or ability of students in the teaching process so that the standard of lessons and teaching methods can be adjusted to the power and strength of their minds.

c) Teachers not to be hard on their students in educating them.

d) Teachers should fill their free time with useful activities.

e) Teachers should provide good role models to students, because role models are seen as a powerful way to build morals and instill praiseworthy principles in the souls of students. ${ }^{20}$

According to the researcher's observations, it shows that the teacher's obligation to teach in the classroom should the teacher continue to add insight into teaching, including mastering learning methods. The teacher must be able to attract the attention of students, keep them open, and develop their own minds. Teachers must accustom good behavior to their students, set an example, and not teach them with words alone.

4. Material Design for the Type of Cooperative Learning Model Group Investigation

Implementation of type cooperative group investment learning model is a learning model that has been arranged in a learning design or RPP in designing learning materials.

a. Introduction

The teacher provides greetings and attendance to students, the teacher provides motivation for students, and the teacher informs students about the learning steps to be carried out.

b. Core activities

The implementation of the type of cooperative learning model is in group investment accordance with the results of interviews by fiqih teachers who state that:

In implementing the type of cooperative learning model group investigation, I first saw the material given then designed the implementation steps. Furthermore,

${ }^{20}$ Rosita, S.Pd., Kepala MTs Alkhairaat Madinatul Ilmi Dolo, Wawancara. Ruang Kamad. 21 Agustus 2019

e-ISSN: 2715-4572 p-ISSN: 2716-1439 
according to the subject matter to be taught, the fasting material is very suitable for the cooperative model type of group investigation, where I divide the group into each student, each of 5 people, divided into four groups. ${ }^{21}$

The statement illustrates that in the implementation of the cooperative learning model, the type of group investment is when the teacher has designed the implementation process in the lesson plan so that the teacher is directed to implementing it.

Irmayanti Iroth, a fiqih teacher again said that in applying the steps of the type cooperative learning model group investment, as follows.

1) The teacher divides heterogeneous groups of 5 each along with the title of the material to be studied and where my group of students combines students who are less active in participating to students who are actively participating.

2) The teacher explains the material for the purpose of learning and group assignments, meaning that the teacher first explains the material to be studied, and then how students can understand the material that I will provide, the explanation can be given at the beginning or at the end, the explanation must be relevant to the goal, the teacher can provide an explanation if there are student who have questions or have been previously designed by the teacher

${ }^{21}$ Irmayanti Iroth, S.Ag., Guru Fikih MTs Alkhairaat Madinatul Ilmi Dolo, Wawancara. Ruang Guru. 15 Oktober 2019 and given assignments to be reviewed by students in each group.

3) The teacher calls the leaders for a material assignment so that one material/task is different from other groups where group one discusses understanding, conditions, and pillars of fasting, group two discusses sunnah fasting, group three discusses nadzar fasting, and group four discusses about Ramadan fasting.

4) Each group discusses existing material cooperatively containing findings, meaning that the teacher provides the opportunity to cooperate with each group in investigating (compiling) the material or cardboard given.

5) After finishing the discussion, through the spokesperson, the chairperson delivered the results of the group discussion, I mean to call the groups one by one who will explain their findings and be given the opportunity to ask other groups.

6) The closing is Hamdalah, Read Prayer, and Greetings. ${ }^{22}$

Based on the researcher's observations, in applying the cooperative learning model type that is an investigation group, the teacher divides the class into several heterogeneous groups. The teacher then explains the purpose of learning and group assignments, the teacher calls the leaders for one task material so that one group gets a task of one material/task that is different from Another group,

\footnotetext{
${ }^{22}$ Irmayanti Iroth, S.Ag., Guru Fikih MTs Alkhairaat Madinatul Ilmi Dolo, Wawancara. Ruang Guru. 15 Oktober 2019
} 
each group discusses the existing material cooperatively containing findings, after completion of the discussion, through the spokesperson, the chairperson delivers the results of the group discussion, the teacher provides a brief explanation as well as provides conclusions, evaluations, and conclusions.

\section{c. Closing activities}

The teacher provides opportunities for students to ask assignment material that is not understood, the teacher and the students reflect on the learning activities and learning outcomes that day, and the teacher gives grades, prizes, praise to outstanding students, and gives assignments.

\subsection{Results of Implementation of Cooperative Learning Model Group Investigation}

Increase the participation of learners in the classroom is very important because with the participation of learners in the learning process indicates that there is no feedback of learners, so that there is continuity between teachers and learners.

In the implementation of the type cooperative learning model, group investigation, it is certainly expected that there will be an increase in the interaction of students' learning participation from several indicators of learning participation; in this presentation, the researcher will describe according to the findings in the field. So that this discussion will integrate existing research results as well as integrate with existing theories and characteristics.

1. Appreciation for the group

This reward system triggers group members' motivation to obtain it. Therefore, efforts to increase student participation are carried out by providing learning methods or models that can motivate students to be willing to participate in the teaching and learning process. This is in the statement of the fiqih teacher, who said as follows.

Providing a method in teaching is certainly boring for students, therefore, as a teacher, I as a teacher must provide a variety of methods and learning models that can stimulate students to be active and participate in class so that the material provided can be well received. In addition to methods and models, I also provide motivations, rewards, or rewards so that students are enthusiastic in learning and to groups that are good and correct in arranging them so that they can develop their thoughts and feelings so that learning objectives and shared responsibility can be achieved so that the learning process can run effective and efficient. ${ }^{23}$

According to the results of observations, researchers see that the efforts given by the teacher to their students are so that students can increase their learning participation in the learning process. The teacher applies several learning methods and models; besides that, the teacher also provides motivation and appreciation (reword) to

${ }^{23}$ Irmayanti Iroth, S.Ag., Guru Fiqih MTs Alkhairaat Madinatul Ilmi Dolo, Wawancara. Ruang Guru. 15 Oktober 2019 
their students to be more enthusiastic in learning and to the group in a good and correct way to arrange it (sticking to the classroom wall). Stated by a student named Moh. Lutfi Alhusaini.

I am from group two; the teachers give us an appreciation for our group because we are the best way to arrange it properly, properly, and neatly among friends or other groups. And the result of our group work, the teacher pasted our cardboard on the classroom wall as a reward for our group, namely two. ${ }^{24}$

The researcher concluded that for the best group, how to arrange properly, correctly, and neatly, the teacher gave awards in the form of good words and cardboard paper that was posted or displayed on the classroom wall for active group cooperation.

The implementation of learning always aims to achieve the desired learning objectives, namely increasing the learning participation of students in order to get good learning outcomes. The teacher is one of the elements in the field of education that has a role and is responsible for improving learning outcomes and participation. The teacher is not only a teacher who teaches various sciences to students, but also as an educator who teaches personality values and is also a guide who provides direction and guides students in learning. For this reason, the teacher actually has a very important role in the

${ }^{24}$ Moh. Lutfi Alhusaini, Peserta didik Kelas VIII B MTs Alkhairaat Madinatul Ilmi Dolo, Wawancara. Ruang Kelas. 25 September 2019 teaching and learning process as an effort to always involve students in the learning process. Therefore, of course, the teacher always finds the obstacles faced in carrying out the learning process both in planning and in its implementation. Therefore each method or learning model has both shortcomings and obstacles.

1. Equal opportunity for success.

Equal opportunity for success means that all students contribute to their group's success through efforts to improve their learning outcomes. This matter presents a challenge to students with different levels of ability to bring out their best in an effort to contribute scores to their group, as explained by the fiqh teacher Irmayanti Iroth as follows.

In my opinion, the application of the group investigation type cooperative learning model in increasing the learning participation of students is very good because there is group togetherness in terms of mutual success. After all, the opportunities for students who are less participating in joining the students who actively participate in the learning process can cooperate with each other towards the group's friends, so friends who are less active in interaction will become active. And there is a goal of the same view of students in carrying out tasks. ${ }^{25}$

According to the results of the researchers' observations that, by applying the cooperative learning model

${ }^{25}$ Irmayanti Iroth, S.Ag., Guru Fikih MTs Alkhairaat Madinatul Ilmi Dolo, Wawancara. Ruang Guru. 15 Oktober 2019 
type of group investigation. Students who were less active if they joined actively participating students would become active, and there would be success and common goals towards each other.

1. Sharing Idea

In the implementation of the cooperative learning model, the type of group investigation, students actively participated because of the exchange of ideas (sharing of ideas) so that the learning process could solve the problem. They were stated by the fiqh teacher Irmayanti Iroth.

In my opinion, with the group investigation type cooperative learning model in carrying out the teaching and learning process, we can find students actively interacting in exchanging ideas compared to other learning models that I have applied, and if students have difficulty learning, of course, other friends will provide them ideas or if there are ideas that they do not really understand of the problems faced by students their friend can help. ${ }^{26}$

According to the observations, the researcher saw that the participation of students actively interacted and collaborated in terms of sharing ideas, and if students did not understand the material provided by the teacher, they did not just ask the teacher but ask other friends.

Observations are used to obtain data in the field to start knowing the

26Irmayanti Iroth, S.Ag., Guru Fikih MTs Alkhairaat Madinatul Ilmi Dolo, Wawancara. Ruang Guru. 15 Oktober 2019 situation and start describing the situation with the data generated from these observations, the learning participation of students in the implementation of group investigation with the type of cooperative learning model. Suppose the teacher implements the cooperative learning model type group investigation. In that case, the majority of students experience a significant increase in learning participation, and the minority experience relatively less improvement, as seen from the table.

\section{Conclusion}

Results of the Implementation of Group Investigation with the type of Cooperative Learning Model is increasing student Participation in the Class VIII B Fiqih Subjects in MTs. Alkhairaat Madinatul Ilmi Dolo that are; Group appreciation, Equal opportunity for success. A study group will receive an award if it succeeds in achieving the success criteria set by the teacher and brainstorming (sharing ideas).

Students' Learning Participation in the Implementation of the Group Investigation Type Cooperative Learning Model before, namely: from 20 students that, the results of students' learning participation in interaction activities they were classified as low because seeing from the students, compiling only 7 people, responding (asking and answering) only 7 people and accepting in the teacher's explanation only 10 people and indicators of learning participation of students were classified to low when seen from the skill scores of these 
students. Meanwhile, after the implementation of the group investigation type and cooperative learning model, it experienced a significant increase. There were 20 students. That the results of student participation in interaction activities compose 19 people, the amount that responds (ask and answer) 14 people, and accept in the teacher's explanation 14 people and indicators of increasing student learning participation also increase, it can be seen that the skill value of these students.

\section{REFERENCES}

Al-Qur'an Karim. Departemen Agama RI. Al-Qur'an dan Terjemahannya, Jakarta: PT. Karya Insan Indonesia, 2004.

Abu Abdurrahman Ahmad bin Syu'aib bin Ali bin Sinan bin Bahr bin Dinar alKhurasani, Sunan an-Nasa'I, Riyadh: Pustaka Ma'arif, 1417 H.

Ahmad, Ilif Khoiru dkk. Strategi Pembelajaran Sekolah Terpadu: Pengaruhnya terhadap Konsep, Mekanisme dan Proses Pembelajaran Sekolah Swasta dan Negeri, Cet.I; Jakarta: Prestasi Pustaka Publisher, 2011.

Ali, Muhammad Daud. Hukum Islam, Jakarta: PT Raja Grafindo Persada, 2007.

Mudlofir dan Evi Fatimatur Rusydiyah. Desain Pembelajaran Inovatif: Dari Teori ke Praktik, Cet. I; Jakarta: PT RajaGrafindo Persada, 2017.
Arif, Arifuddin. Tanya Jawab Masalah Pendidikan dan Pembelajaran, Cet. I; Palu: EnDeCe Press, 2011.

Arsyad, Ashar. Media Pembelajaran, Jakarta: PT Raja Grafindo, 2002.

Astuti D., Siti Irene. Desentralisasi dan Partisipasi dalam Pendidikan, Yogyakarta: UNY., 2009.

Aunurrahman. Belajar dan Pembelajaran, Bandung: PT Alfabeta, 2010.

Badudu dan Zain. Kamus Umum Bahasa Indonesia, Cet. IV; Jakarta: PT Pustaka Sinar Harapan, 2001.

Beni Ahmad Saebani dan Januri. Ushul Fiqh, Bandung: Pustaka Setia, 2008.

Departemen Agama Republik Indonesia. Kurikulum Madrasah Tsanawiyah: Standar Kompetensi, Jakarta: Depag RI, 2005.

Etin Solihatin dan Raharjo. Pembelajaran Kooperatif: Analisis Model Pembelajaran IPS, Cet. IV; Jakarta: PT Bumi Aksara, 2012.

Evita, E., Syahid, A., \& Nurdin, N. (2019). Understanding Students' Learning Outcomes Differences Through the Application of the Market Place Activity Type of Cooperative Learning Model and the Application of Conventional Learning Models International Journal of Contemporary Islamic Education, 1(1), 67-85.

Fanani, Ahmad. Kamus Inggris Indonesia, Cet. I; Surakarta: PT Open Books, 2014.

Gafur, Abdul. Desain Pembelajaran: Konsep, Model, dan Aplikasinya dalam Perencanaan Pelaksanaan Pembelajaran, Yogyakarta: Penerbit Ombak, 2012. 
Hamdani. Strategi Belajar Mengajar, Bandung: CV Pustaka Setia, 2011.

Hamalik, Oemar. Kurikulum dan Pembelajaran, Cet. VIII; Jakarta: Bumi Aksara, 2008.

Hamzah. Model Pembelajaran: Menciptakan Proses Belajar Mengajar yang Kreatif dan Efektif, Cet. I; Jakarta: Bumi Aksara, 2007. dan Nurdin Mohamad. Belajar dengan Pendekatan PAILKEM, Cet. I; Jakarta: PT Bumi Akasara, 2011.

Hasbullah. Dasar-Dasar Ilmu Pendidikan, Cet. X; Jakarta: PT RajaGrafindo Persada, 2012.

Herawati, Yeni. Peningkatan Partisipai Siswa dalam Pembelajaran Biologi Melalui Optimalisasi Penggunaan dengan Metode Pembelajaran Problem Based Learning, Surakarta: FKIP UNS, 2008.

Joyce, Bruce and Marsha Weil, Models of Teaching (Second Edition). Englewood Cliffs, New Jersey: PrenticeHall, Inc, 1980.

Kurniasih, Imas dan Berlin Sani. Ragam Pengembangan Model Pembelajaran untuk Peningkatan Profesionalitas Guru, Yogyakarta: Kata Pena, 2015.

Lampiran Keputusan Menteri Agama Republik Indonesia Nomor: 165 Tahun 2014, Tentang Kurikulum 2013 Mata Pelajaran Pendidikan Agama Islam dan Bahasa Arab pada Madrasah.

Mattew B. Milles, dan A. Michael Huberman. Quantitative Data Analisis. Diterjemahkan oleh Tjeptjep Rohendi, analisis data kuantitatif, Cet. I: Jakarta: UI-Pres, 1992.
Meleong, Lexy J. Metodologi Penelitian Kualitatif, Cet. XIII; Bandung: PT. Remaja Rosdakarya, 2001.

Muhammad Thobroni dan Arif Mustafa. Belajar dan Pembelajaran: Pengembangan Wacana dan Praktik Pembelajaran dalam Pembagunan Nasional, Cet. II; Yogyakarta: ArRuzz Media, 2013.

Muhaimin. Pengembangan Kurikulum Pendidikan Agama Islam, Jakarta: Raja Grafindo Persada, 2005.

Mulyana, Deddy. Metode Penelitian Kualitatif, Bandung: Remaja Rosda Karya, 2004.

Munthe, Bermawati. Desain Pembelajaran, Yogyakarta: PT Pustaka Insan Madani, 2009.

- Desain Pembelajaran, Cet. V; Yogyakarta: Insan Madani, 2011.

Nana Sudjana dan Wari Suwariyah. Model-model Mengajar CBSA, Bandung: CV Sinar Baru, 1991.

Nasution, S. Metode Research, Cet: VI, Jakarta: Bumi Aksara, 2003.

Metode Research, Cet. IV,

Jakarta: Bumi Aksara, 2004.

Nata, Abuddin. Perspektif Islam tentang Strategi Pembelajaran, Cet.III; Jakarta: Kencana, 2014.

Nugraheni, Aninditya Sri. Penerapan Strategi Cooperative Learning dalam Pembelajaran Bahasa Indonesia, Yogyakarta: PT Pustaka Insan Madani, 2012.

Nunung Suryani dan Leo Agung. Strategi Belajar Mengajar, Yogyakarta: Ombak, 2012.

Nunung Nurhayati, "Meningkatkan Partisipasi Siswa Melalui 
Pembelajaran

PAIKEMGembrotdiDalamKelas". BlogNunungNurhayati,http://nh uynhuy1994.blogspot.co.id/2014 /06/meningkatkan-partisipasisiswa-melalui.html (17 Januari 2019).

Nurdin, N. (2017a). Research in Online Space: The Use of Social Media for Research Setting Jurnal Sistem Informasi (Journal of Information System), 13(1), 67-77.

Nurdin, N. (2017b). To Research Online or Not to Research Online: Using Internet-Based Research in Islamic Studies Context. Indonesian Journal of Islam and Muslim Societies, 7(1), 31-54.

Nurdin, N., \& Yusuf, K. (2020). Knowledge management lifecycle in Islamic bank: the case of syariah banks in Indonesia. International Journal of Knowledge Management Studies, 11(1), 59-80. https://doi.org/10.1504/ijkms.20 20.105073

Nurdin, N., Pettalongi, S. S., \& Ahsan, M. N. (2019, 30-31 July 2019). Implementation of Teaching Quality Assessment System Using Android. 2019 5th International Conference on Science and Technology (ICST)

Nurdyansyah dan Eni Fariyatul Fahyuni. Inovasi Model Pembelajaran: Sesuai Kurikulum 2013, Cet. I; Sidoarjo; Nizamia Learning Center, 2016.

Pettalongi, Saggap S. Manajemen dalam Pendidikan, Cet.I; Yogyakarta: Gava Media, 2016.
Peter Salim dan Yenny Salim. Kamus Bahasa Indonesia Kontemporer, Ed. III; Jakarta: PT Modern English Press, 2002.

Peraturan Menteri Agama Republik Indonesia Nomor 2 Tahun 2008, Tentang Standar Kompetensi Lulusan dan Standar Isi Pendidikan Agama Islam Dan Bahasa Arab di Madrasah.

Priansa, Donni Juni. Pengembangan Strategi dan Model Pembelajaran, Inovatif, Kreatif, dan Prestatif dalam Memahami Peserta Didik, Cet. I; Bandung: Pustaka Setia, 2017.

Ramulyo, Mohd Idris. Asas-asas Hukum Islam, Jakarta: Sinar Grafika, 2004.

Ratumanan, TG Inovasi Pembelajaran: Mengembangkan Kompetensi Peserta didik Secara Optimal, Yogyakarta: Penerbit Ombak, 2015.

Risnayanti. Implementasi Pendidikan Agama Islam di Taman Kanak-kanak Islam Raliya Jaya Villa Dago Pamulang, Skripsi, Jakarta: Perpustakaan Umum, 2004.

Rusli, R. (2014). Teaching Usul al-Fiqh: A Multicultural Education Model. Al-Tahrir: Jurnal Pemikiran Islam, 14(2), 447-464.

Rus'an. Model-Model Pembelajaran Berbasis PAKEM, Cet. II; Bogor: PT Flashbook, 2012.

Rusman. Model-model Pembelajaran, Jakarta : Rajawali Pers, 2011.

Model-Model Pembelajaran: Mengembangkan Profesional Guru, Ed. II; Jakarta: PT Raja Grafindo Persada, 2010.

Model-Model Pembelajaran: Mengembangkan Profesional Guru, Cet. II; Jakarta: PT Raja Grafindo Persada, 2011.

e-ISSN: 2715-4572 p-ISSN: 2716-1439 
Model-Model Pembelajaran: Mengembangkan Profesional Guru, Ed. II; Cet. VI; Jakarta: PT RajaGrafindo Persada, 2013.

Sagala, Syaiful. Superoisi Pembelajaran dalam Profesi Pendidikan, Cet. I; Bandung: Alfabeta, 2010.

Sani, Ridwan Abdullah. Inovasi Pembelajaran, Cet. III; Jakarta: Bumi Aksara, 2015.

Sanjaya, Wina. Strategi Pembelajaran: Berorientasi Standar Proses Pendidikan, Cet,II; Jakarta: Kencana, 2007. Perencanaan dan Desain Sistem Pembelajaran, Cet, II; Jakarta: Kencana, 2009.

Sharan, Shlomo. The Handbook of Cooperative Learning: Inovasi Pengajaran dan Pembelajaran Untuk Memacu Keberhasilan Siswa di Kelas, Penerjemah: Sigit Prawoto, Cet. I; Yogyakarta: Istana Media, 2014.

Sholeh, Khabib dkk. Kecerdasan Majemuk Berorientasi Pada Partisipasi Peserta didik, Cet. I; Yogyakarta: Pustaka Pelajar, 2016.

Slavin, Robert E. Educational Psychology: Theory and Practice (Psikologi Pendidikan: Teori dan Praktek) Penerjemah: Marianto Samosir, Ed. IX; Cet. I; Jakarta: PT Indeks, 2011.

Sudarto. Metodologi Penelitian Filsafat, Cet. I; Jakarta: PT. Raja Grafindo Persada, 1996.

Sugiyono. Metode Penelitian Pendidikan, Cet. IX; Bandung: Alfabeta, 2010. Metode Penelitian Pendidikan,

Cet: II, Bandung: Alfabeta, 2011.
Suhana, Cucu. Konsep Strategi Pembelajaran, Cet. IV; Bandung: PT Refika Aditama, 2014.

Sumiati dan Asra. Metode Pembelajaran, Bandung: CV. Wacana Prima, 2008.

Sundariningrum. Klasifikasi Partisipasi, Jakarta: Grasindo, 2001.

Suprihatinigrum, Jamil. Strategi Pembelajaran : Teori dan Aplikasi, Cet. III; Jogjakarta: Ar-Ruzz Media, 2016.

Suryosubroto. Proses Belajar Mengajar di Sekolah, Jakarta: PT Rineka Cipta, 1997.

Proses Belajar Mengajar di Sekolah, Jakarta: PT Rineka Cipta, 2007.

Susanto, Ahmad. Teori Belajar dan Pembelajaran di Sekolah Dasar, Jakarta: Kencana Prenada Media Group, 2013.

Syaiful Bahri Djamarah dan Aswan Zain. Strategi Belajar Mengajar, Cet.III; Jakarta: Rineka Cipta, 2006.

Thobroni, M. Belajar dan Pembelajaran: Teori dan Praktik, Cet. I; Yogyakarta: Ar-Ruzz Media, 2015.

Trianto. Mendesain Model Pembelajaran Inovatif-Progresif Konsep Landasan, dan Implementasi Pada KTSP, Jakarta: Prenada Media Group, 2009.

Ulum, Bakhrul. Mata Pelajaran Fikih,. http:// blogeulum.blogspot.com/201 3/02/mata-pelajaran-fiqih.html. $\quad$ (30 Juni 2020)

Uno, Hamzah B. Model Pembelajaran: Menciptakan Proses Belajar Mengajar yang Kreatif dan Efektif, Cet. X; Jakarta: Bumi Aksara, 2014.

e-ISSN: 2715-4572 p-ISSN: 2716-1439 
Usman, Husaini at.al. Metode Penelitian Sosial, Cet. III; Jakarta: Bumi Aksara, 2000.

Warsono dan Hariyanto. Pembelajaran Aktif: Teori dan Asesmen, Cet. IV; Bandung: PT Remaja Rosdakarya, 2016.

Wasi al-Fahmi,Ahmad."Pembelajaran Inovatif II'. Blog Huda Wasi,http://hudawasi.bolgspot.co.id/2015/06/ mak alah-group-investigation.html (06 Maret 2019)

Wena, Made. Strategi Pembelajaran Inovatif Kontemporer: Suatu Tinjauan Konseptual Operasional, Cet. IX; Jakarta: PT Bumi Aksara, 2014.

Yusuf, Chairul Fuad. Inovasi Pembelajaran Agama Islam (SMP), Cet. I; Jakarta: Pene Cipta Satria, 2007.

Zaini, Hisyam dkk. Strategi Pembelajaran Aktif, Yogyakarta: Pustaka Insan Madani, 2008.

Zakaria, Azra'ie. Kosep Pendidikan Ibnu Khaldun : Relevansinya dengan Pendidikan Modern, Jakarta : LP2 M Universitas Islam AsySyafieiyah, 2011. 